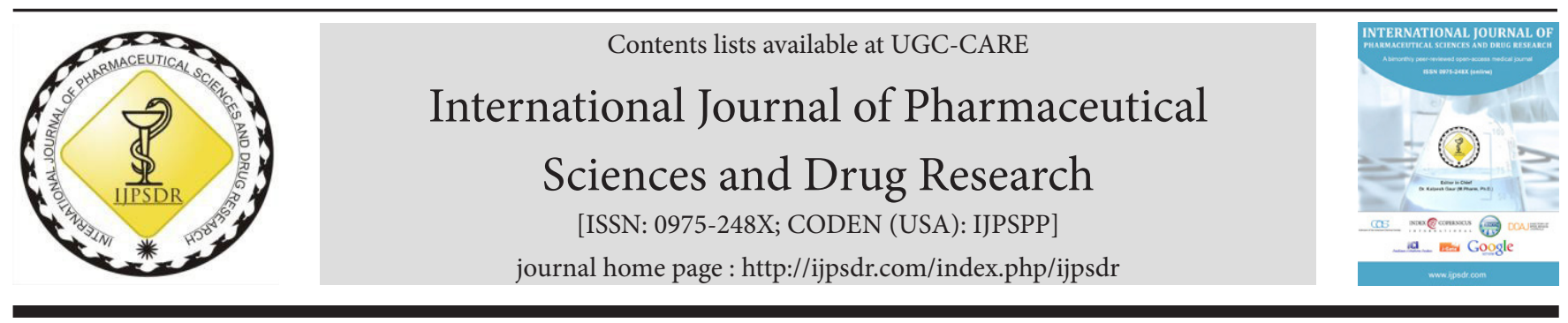

Research Article

\title{
Investigating Drug Properties of Bioactive Compounds of Cymbopogon citratus by Absorption, Distribution, Metabolism, Excretion/Toxicity and Molecular Docking Analysis Against Apolipoprotein N-Acyl Transferase
}

\author{
Abhishek Biswal R, Riyaz Sharif S, Vivek Pazhamalai* \\ Department of Bio-Engineering, Vels Institute of Science Technology and Advanced Studies (VISTAS), Chennai- 600117, Tamil Nadu, India
}

\author{
A R T I C L E IN F O \\ Article history: \\ Received: 06 December, 2019 \\ Revised: 21 January, 2020 \\ Accepted: 23 January, 2020 \\ Published: 30 January, 2020 \\ Keywords: \\ ADME/T prediction, Autodock, \\ Apolipoprotein n-acyl \\ transferase, Cymbopogon \\ citratus, In silico, Molecular \\ docking. \\ DOI: \\ 10.25004/IJPSDR.2020.120113
}

\begin{abstract}
A B S T R A C T
Delivering a potential drug is a predominant challenge in medicinal chemistry. In this study, bio-organic compounds of Cymbopogon citratus was screened by analysing physiochemical properties like solubility, permeability, efficacy, toxicity, and metabolic stability. The optimization of drug potential against virulent protein was calculated by using docking algorithm Autodock 4.2.3. Structure-based ligand docking reveals that the compounds had better inhibition potential against virulent enzymes with insoluble and impermeable activities. The organic compounds of Cymbopogon citratus were screened using Lipinski rule of five and absorption, distribution, metabolism, excretion/toxicity (ADME/T) prediction for drug likeliness. The structure-based ligand docking was done between bioactive compounds of plant and virulent protein that cause diseases. The interaction was visualized using Discovery studio and were studies. The molecular docking of bioactive compounds resulted in better inhibition potential with controlled lipophilicity level, without causing toxicity that harms the natural habitat of humans. The compounds, 1,3,4-trimethyl -3cyclohexene-1-carboxaldehyde, exhibit binding energy $-4.70 \mathrm{Kcal} / \mathrm{mol}$ followed by $\beta$-myrcene $-4.35 \mathrm{Kcal} / \mathrm{mol}$ and Geraniol $-4.35 \mathrm{Kcal} / \mathrm{mol}$. Hence, structure-based ligand docking and in silico ADME/T studies revealed that the compounds have better inhibition potential against Apolipoprotein by improving the prediction of drug compounds.
\end{abstract}

\section{IN TRODUCTION}

Lipoproteins assumes a significant job in layer biogenesis correspondingly as a few diverse cells work in the cellular functions. In microorganisms, lipoproteins are engaged with orchestrating pre-prolipoproteins inside the cytoplasm. ${ }^{[1]}$ Each prolipoprotein contains partner degree N-terminal sign amide that has a cysteinecontaining 'lipobox' that contains amino alkanoic corrosive grouping of Leu-Ala-Gly-Cys. At the point when it is being co-translationally translocated by Sec/ Tat translocon frameworks to the periplasm, the lipidation of pre-prolipoprotein is successively catalyzed by the resulting three chemicals to make a develop conjugated protein. The chemicals are (I) diacylglycerol (DAG) adjustment of pre-prolipoproteins by phosphatidylglycerol
(PG): prolipoprotein DAG transferase (Lgt) to frame prolipoproteins; (ii) cleavage of sign peptide from prolipoproteins by lipoprotein signal peptidase (LspA) to shape Apolipoprotein $\mathrm{N}$-acyl Transferases; and (iii) $\mathrm{N}$-acylation of Apolipoprotein by Apolipoprotein $\mathrm{N}$-acyl Transferase (Lnt). ${ }^{[2]}$

Cymbopogon citratus belongs to the family of Poaceae, which is an aromatic grass of $1.5 \mathrm{~m}$ tall. This plant is not known in a wild situation habitat and is widely cultivated in tropics and gardens, especially near South Asia. This tropic plant is probably originating in Sri Lanka and Malaysia. Cymbopogon citratus is widely found at an elevation up to 1,400 meters. This plant may be killed at a temperature below $10^{\circ} \mathrm{C} \cdot{ }^{[3,4]}$ Cymbopogon citratus is eaten as a vegetable with rice and also a refreshing tea which can be brewed from these leaves. These leaves are

\footnotetext{
*Corresponding Author: Mr. Vivek Pazhamalai

Address: Department of Bio-Engineering, Vels Institute of Science Technology and Advanced Studies (VISTAS), Chennai- 600117, Tamil Nadu, India Email $\square$ : viveksncet2011@gmail.com

Relevant conflicts of interest/financial disclosures: The authors declare that the research was conducted in the absence of any commercial or financial relationships that could be construed as a potential conflict of interest.

Copyright (C) 2020 Abhishek Biswal R et al. This is an open access article distributed under the terms of the Creative Commons AttributionNonCommercial-ShareAlike 4.0 International License which allows others to remix, tweak, and build upon the work non-commercially, as long as the author is credited and the new creations are licensed under the identical terms.
} 
also used to treat fever, cold, cough, and stomach upset. The tea has diuretic properties and can help in curing urination difficulties and water retention. This plant is used for the cellulose and production of paper. Cymbopogon citratus is a plant considered for economic importance, which forms a bedrock farming system in the United States of America and the south part of Asia. Cymbopogon citratus is used as a scent in many products like soap, perfume, candle, mosquito, and another insect repellent. Fresh leaves of this species are crushed and used as a shampoo, and the annual foliage yield is 30-50 tons per hectare. This plant exhibits to be a fungicide in treating pathogenic fungi on the cultivated jatropha curcas plant. This plant contains many phy tochemical compounds such as flavonoids and phenolic compounds which consist of luteolin, quercetin, isoorientin, kaempferol, and apigenin. The compounds are mainly alcohol, ketones, aldehyde, and esters. The plant was used for pharmacological activities like anti-bacterial, anti-filarial, anti-fungal, and some other properties. Lemongrass is a bitter, aromatic, and a cooling herb that increases the perspiration and relieves spasms. The extracted oil from the plant is used in the effective treatment of skin conditions including athlete's foot, ringworm, and scabies. ${ }^{[5]}$ The pain at the arthritic joints also treated using this plant. In this research, the bioactive compounds of lemongrass will be structurally docked against the virulent enzymes of Apolipoprotein $\mathrm{n}$-acyl transferase that causes urine infectious disease. ${ }^{[6]}$

\section{Materials AND Methods}

\section{Bioactive Compounds of Obtained from Gas Chromatography-mass Spectroscopy (GC-MS) Analysis of Cymbopogon citratus}

From the plant of Cymbopogon citratus 43 compounds were revealed by using GC-MS in which 8 compounds were selected as that were expected their presence in essential oil. It is commonly known that grass plants produce terpenoid hydrocarbons that can be used in medicinal, industrial, and perfumery. The major compounds reported are citral (34.8\%), neral (30.72\%), $\beta$-myrcene (11.28\%), Geranyl acetate (0.57\%), Bicyclo[3.1.1] heptane2Carboxaldehyde-6,6-dimethyl (0.23\%), geraniol (5.54\%), 1,3,4-trimethyl-3cyclohexene-1-carboxaldehyde (2.20\%), citronellol (1.34\%) and D-limonene (0.03\%). ${ }^{[7,8]}$ its citral content mainly determined the lemon grass quality. Citral (3,7- dimethyl-2,6-octadienal) consists of the cis-isomer geranial and also the trans-isomer neral. These bioactive compounds were screened using Lipinski rule of five and ADME/T properties for knowing the drug likeliness.

\section{Protein Target Confirmation}

The apolipoprotein $\mathrm{N}$-acyl transferase (PDB ID: $5 \mathrm{XHQ}$ ) was utilized as a medication focus in this examination work with goals $2.587 \AA$ and $\mathrm{X}$ beam diffraction technique. The protein was recovered from Protein Information Bank that comprises of two chains A and B. This chemical contains an exo-layer nitrilase space melded to a transmembrane (TM) area. The TM space of Lnt contains eight TM helices, which structure a layer installed pit with a sidelong opening and a periplasmic exit. The hydrophobic particles were evacuated for better ligand restricting proclivity that meddles in the crystallographic structures. The protein structure with the dynamic site appeared in Fig. 1. The ligand library was recovered from pubchem (https://pubchem.ncbi.nlm.nih.gov/), which was kept up by the National Focus of Biotechnology Data. The ligand was additionally screened for Lipinski rule of five by
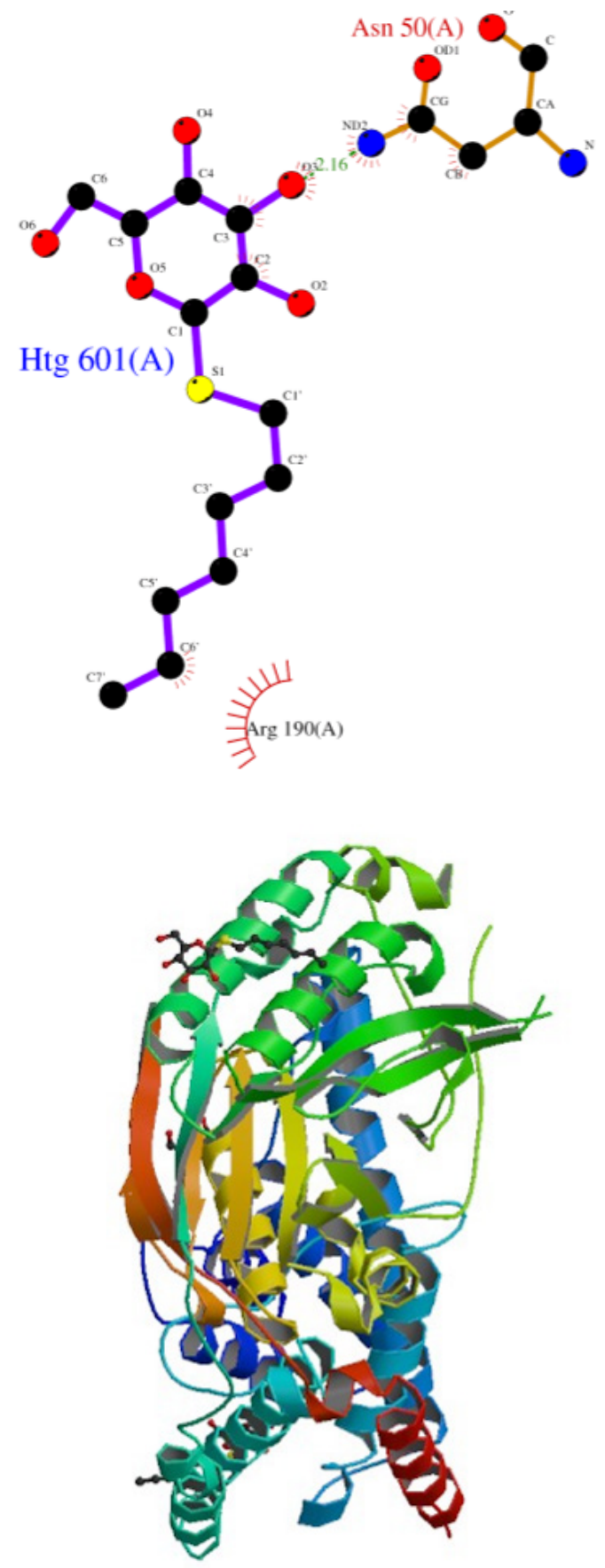

Fig. 1: Ligplot and 3D structure of Apolipoprotein N-acyl Transferase 
following certain criteria like rotatable bonds $<10, \log P$ $<5$, hydrogen bond contributor $<5$, hydrogen bond acceptor $<10$ Molecular mass $(<500)$ and molar refractivity $(<130)$.

\section{Absorption, Distribution, Metabolism, Excretion and Toxicity properties of Bioactive Compounds from Essential Oil}

The expectation of ADME/T quality of the bioactive mixes were finished utilizing swiss ADME. These properties characterize the real condition of ligand by breaking down water solvency, gastrointestinal retention, infiltration of a ligand in blood mind obstruction, and focal sensory system. The danger level of the medication atoms was additionally screened with dose level for humans and rodents. These properties fundamentally run dependent on the guideline of vector-based calculation that can without much of a stretch break down informational collections of referred to inhibitor/non-inhibitor just as substrate/non-substrate. ${ }^{[9-11]}$

\section{Molecular Docking Analysis using Autodock 4.2.6 Software}

Molecular docking is a computational method of chemistry that plays a major role in designing drug molecules. The docking was done with virulent protein against bioactive compounds. The enzymes and receptors are chiral in a form that comprises of enantiomers with same or different biological activities. The rigid form docking was used in which the binding position of the ligand will be stable and binded with different types of amino acids. A default grid size of $20 \AA$ was set. Total grid points per map were 64,000 . Grid spacing was $0.375 \AA$ (default). The center grid box sizes were x center: -16.302 , y center: -23.34 , and -16.245 , respectively. The structure-based ligand docking was done using Autodock 4.2.6 software and was visualized using Discovery Studio 3.1. ${ }^{[12,13]}$

\section{Result AND Discussion}

The following bioactive compounds obtained from Cymbopogon citratus were citral (34.8\%), neral (30.72\%), $\beta$-myrcene (11.28\%), geraniol (5.54\%), 1,3,4-trimethyl -3cyclohexene-1-carboxaldehyde (2.20\%), citronellol (1.34\%). Geranyl acetate (0.57\%), bicyclo [3.1.1] heptane2carboxaldehyde-6,6-dimethyl (0.23\%) and D-limonene $(0.03 \%)$. The bioactive compounds were unique in which no reports are available against the apolipoprotein $\mathrm{N}$-acyl transferase, which paves the way for the discovery of novel phytomedicine. The bioactive compounds were screened using Lipinski rule five in which various parameters were checked like molecular weight, lipophilicity, hydrogen acceptor, and donor.

All the compounds satisfy the Lipinski rule of five, which means compounds do not have virulent factors that may disturb the normal microflora in the human intestine system.

\section{Absorption, Distribution, Metabolism, Excretion and Toxicity Properties}

The bioactive compounds were screened for physiochemical activities by using swiss ADME software. The compounds consist of less water solubility due to oil content in the lemongrass. The intestinal absorption in the oil of lemongrass shows a better result from $92-96 \%$. The values of each property for all the compounds were tabulated in Table 2 . The compounds $\beta$-myrcene has better absorption Table 1: Compounds analyzed in Lipinski rule of five

\begin{tabular}{|c|c|c|c|c|c|}
\hline Compound name & Mass & Hydrogen bond donor & Hydrogen bond acceptor & LOGp & Molar refractivity \\
\hline Citral & 152 & 0 & 1 & 2.87 & 48.48 \\
\hline Neral & 152 & 0 & 1 & 2.87 & 48.48 \\
\hline$\beta$-myrcene & 136 & 0 & 0 & 3.47 & 48.11 \\
\hline Geraniol & 154 & 1 & 1 & 2.67 & 49.50 \\
\hline 1,3,4-trimethyl -3cyclohexene-1-carboxaldehyde & 138 & 0 & 1 & 2.32 & 41.77 \\
\hline Citronellol & 156 & 1 & 1 & 2.75 & 49.53 \\
\hline Geranyl acetate & 196 & 0 & 2 & 3.24 & 59.05 \\
\hline Bicyclo[3.1.1] heptane-2Carboxaldehyde-6,6-dimethyl & 152 & 0 & 1 & 2.25 & 44.16 \\
\hline D-limonene & 136 & 0 & 0 & 3.30 & 45.91 \\
\hline
\end{tabular}

Table 2: Absorption properties of compounds

\begin{tabular}{|c|c|c|c|c|c|c|}
\hline $\begin{array}{l}\text { Compound } \\
\text { name }\end{array}$ & $\begin{array}{l}\text { Water solubility } \\
(\log \mathrm{mol} / \mathrm{L})\end{array}$ & $\begin{array}{l}\mathrm{CaCo}_{2} \text { permeability } \\
\left(\mathrm{Log} \mathrm{Pabb} \text { in } 10^{-6}\right. \\
\mathrm{cm} / \mathrm{Sec})\end{array}$ & $\begin{array}{l}\text { GI absorption } \\
(\%)\end{array}$ & $\begin{array}{l}\text { Skin } \\
\text { permeability } \\
(\text { Log Kp) }\end{array}$ & $\begin{array}{l}\text { P-glyco- } \\
\text { protein } \\
\text { substrate }\end{array}$ & $\begin{array}{l}\text { P-glyco- } \\
\text { protein I } \\
\text { inhibitor }\end{array}$ \\
\hline Citral & -3.337 & 1.504 & 95.31 & -2.413 & No & No \\
\hline Neral & -3.337 & 1.504 & 95.31 & -2.413 & No & No \\
\hline$\beta$-myrcene & -4.497 & 1.4 & 96.69 & -1.043 & No & No \\
\hline Geraniol & -2.866 & 1.49 & 92.78 & -1.511 & No & No \\
\hline 1,3,4-trimethyl -3cyclohexene-1-carboxaldehyde & -1.957 & 1.41 & 97.15 & -2.309 & No & No \\
\hline Citronellol & -2.957 & 1.489 & 92.83 & -1.525 & No & No \\
\hline Geranyl acetate & -3.446 & 1.627 & 94.9 & -1.665 & No & No \\
\hline Bicyclo[3.1.1]heptane-2Carboxaldehyde-6,6-dimethyl & -3.221 & 1.476 & 95.74 & -1.951 & No & No \\
\hline D-limonene & -3.568 & 1.401 & 95.89 & -1.721 & No & No \\
\hline
\end{tabular}


rate in gastrointestinal fluid with less water solubility and less skin permeability.

The essential oil of lemongrass does not have any harmful factors that can cross the blood-brain barrier (BBB) and central neuro system (CNS) as shown in Table 3. All the values are negative in the CNS permeability, which is understood that the compounds have better inhibition potential. The volume of distribution in human is a major parameter which measures the number of drug molecules distributes throughout the body. All the compounds are stable and will not penetrate in the immune system.

The enzymatic transformation in the body plays a major role in the conversion of drugs at a particular active site. These compounds are not involved in any metabolic activities with any substrate and inhibitor of cytochrome
P450 that catalyzes the oxidation reaction, which was shown in Table 4.

The excretion and the toxicity level of the compounds were checked as tabulated in Table 5, and the tolerated dosage of human and rats were noted. While consuming the essential oil of lemongrass, it may be cause little irritation on the skin. The dosage level given for rats and humans can help to perform in silico studies. The dosage level for human as well as a rat was screened using the ADMET modeler ${ }^{\mathrm{TM}}$ module in ADMET Predictor in which the computational toxicology was built.

The bioactive compounds of Cymbopogon citratus were docked against apolipoprotein $\mathrm{N}$-acyl transferase to identify novel therapeutic activities with selective targets and reasonable ADMET properties. The binding structure-

Table 3: Distribution properties of compounds

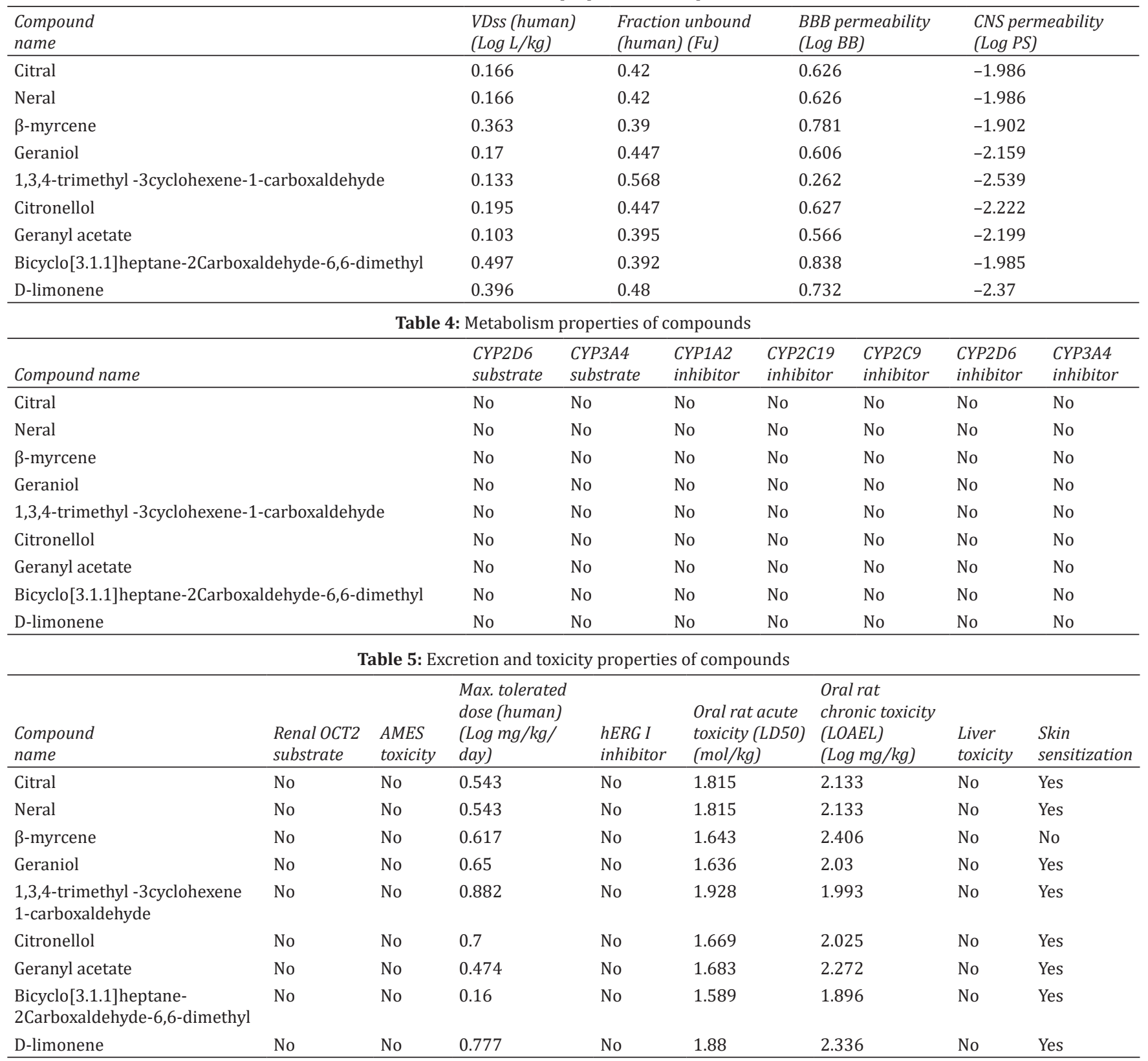




\section{Abhishek Biswal R et al.}

based ligand docking was predicted using Autodock 4.2.3. The crystal structure of the targeted protein (PDB ID: 5XHQ) was retrieved from Protein Data Bank and was docked against the targeted ligand molecule. The binding site of the amino acids was visualized using the discovery studio, in which hydrostatic bonds will be visualized. The detailed interaction of molecules was shown in Figs. 2-3 and the free binding energy was shown in Table 6. As a
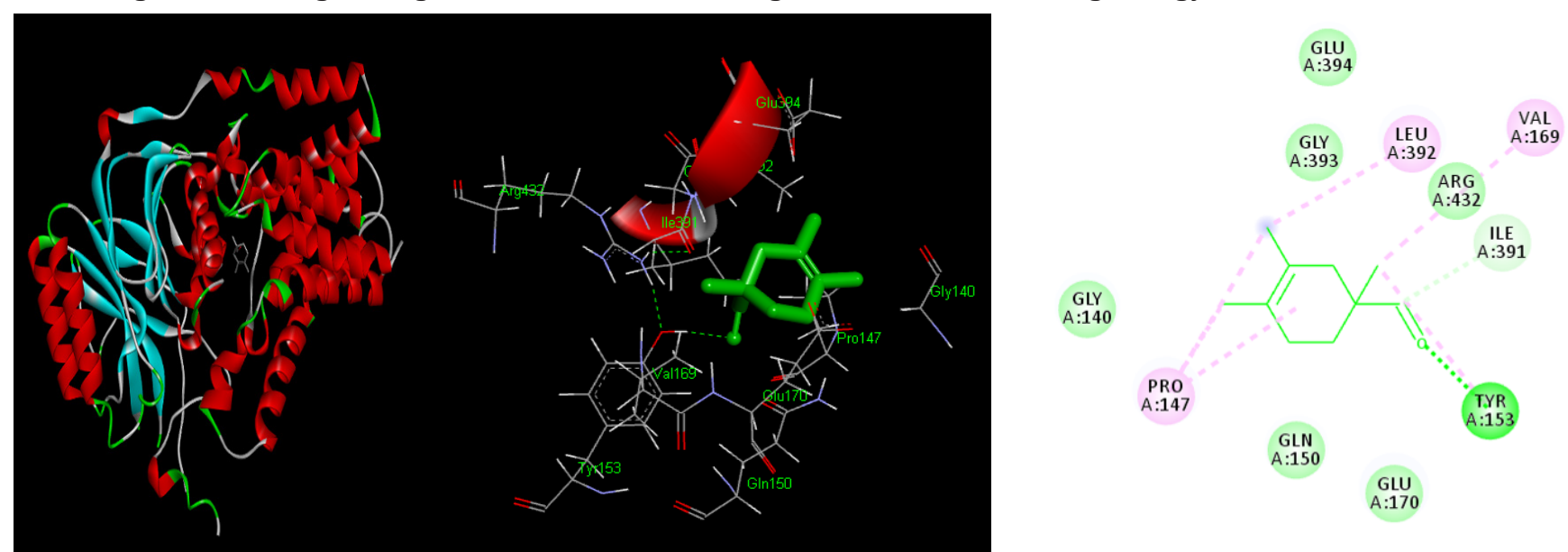

Fig. 2: 2D and 3D interaction of 1,3,4-trimethyl -3cyclohexene-1-carboxaldehyde

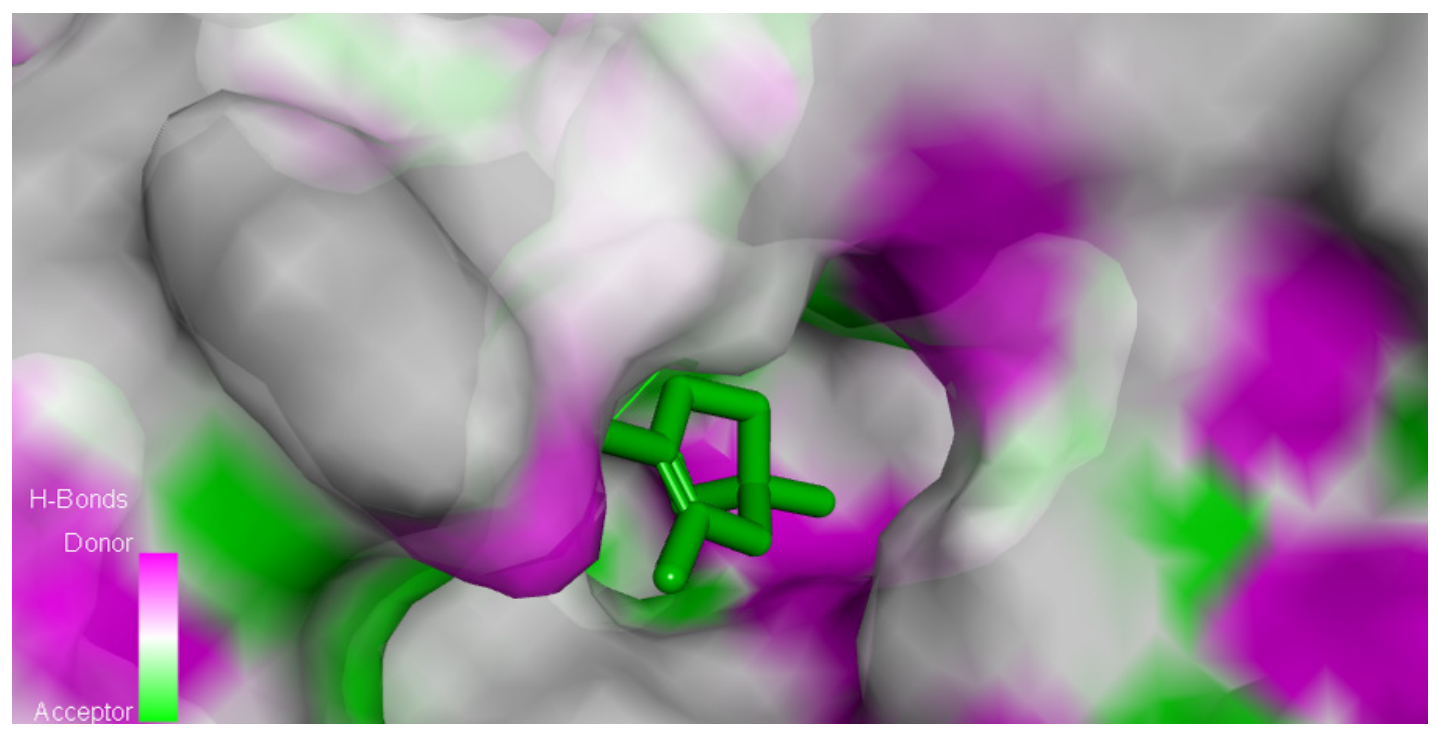

Fig. 3: Hydrogen bond interaction of 1,3,4-trimethyl -3cyclohexene-1-carboxaldehyde

Table 6: Interactions of various bioactive compounds

\begin{tabular}{|c|c|c|c|c|c|}
\hline $\begin{array}{l}\text { Compound } \\
\text { name }\end{array}$ & Binding energy & $\begin{array}{l}\text { Vanderwaals } \\
\text { interaction }\end{array}$ & $\begin{array}{l}\text { No. of hydrogen } \\
\text { bonds }\end{array}$ & $\begin{array}{l}\text { Hydrogen } \\
\text { interactions }\end{array}$ & Total no of residues \\
\hline Citral & -4.16 & $\begin{array}{l}\text { VAL } 75 \text {, PHE } 146 \text {, VAL } 339 \text {, } \\
\text { HIS } 425 \text {, CYS } 387, \text { TRP } 148, \\
\text { PHE } 416 \text {, TYR } 388, \text { TRP } 74\end{array}$ & 0 & 0 & $\begin{array}{l}\text { VAL } 75 \text {, PHE } 146 \text {, VAL } 339 \text {, } \\
\text { HIS } 425 \text {, CYS } 387 \text {, TRP } 148 \text {, } \\
\text { PHE } 416 \text {, TYR } 388, \text { TRP } 74\end{array}$ \\
\hline Neral & -3.91 & $\begin{array}{l}\text { VAL 339, TYR 388, TRP } \\
\text { 148, GLY 421, PRO 422, } \\
\text { CYS 387, PHE 416, HIS } 425 \text {, } \\
\text { ASP 413, TRP } 74 \text {, PHE } 146\end{array}$ & 0 & 0 & $\begin{array}{l}\text { VAL } 339 \text {, TYR } 388 \text {, TRP } 148 \text {, } \\
\text { GLY } 421 \text {, PRO 422, CYS } 387 \text {, } \\
\text { PHE } 416 \text {, HIS } 425 \text {, ASP } 413 \text {, } \\
\text { TRP } 74 \text {, PHE } 146\end{array}$ \\
\hline$\beta$-myrcene & -4.35 & $\begin{array}{l}\text { VAL 339, GLY 421, PHE } \\
\text { 146, TYR 388, TRP 148, } \\
\text { TRP 74, PRO 422, HIS 425, } \\
\text { CYS 387, ASP 413, } \\
\text { PHE 416, GLY 421 }\end{array}$ & 0 & 0 & $\begin{array}{l}\text { VAL } 339 \text {, GLY } 421 \text {, PHE } 146 \text {, } \\
\text { TYR } 388 \text {, TRP } 148 \text {, TRP } 74 \text {, } \\
\text { PRO 422, HIS 425, CYS } 387 \text {, } \\
\text { ASP } 413 \text {, PHE } 416 \text {, GLY } 421\end{array}$ \\
\hline Geraniol & -4.35 & $\begin{array}{l}\text { VAL } 339 \text {, PHE } 146 \text {, VAL } 75 \text {, } \\
\text { TYR } 388 \text {, TRP } 148 \text {, TRP } 74 \text {, } \\
\text { HIS 425, PHE } 416 \text {, CYS } 387 \text {, } \\
\text { PRO 422, GLY } 421\end{array}$ & 0 & 0 & $\begin{array}{l}\text { VAL } 339 \text {, PHE } 146 \text {, VAL } 75 \text {, } \\
\text { TYR } 388 \text {, TRP } 148 \text {, TRP } 74 \text {, } \\
\text { HIS 425, PHE } 416 \text {, CYS } 387 \text {, } \\
\text { PRO 422, GLY } 421\end{array}$ \\
\hline
\end{tabular}


Investigating Drug Properties of Bioactive Compounds of Cymbopogon citratus by ADME/T and Molecular Docking...

Contt.

\begin{tabular}{|c|c|c|c|c|c|}
\hline $\begin{array}{l}\text { 1,3,4-trimethyl -3cyclohexene- } \\
\text { 1-carboxaldehyde }\end{array}$ & -4.72 & $\begin{array}{l}\text { GLU 170, GLN 150, PRO } \\
\text { 147, GLY 140, GLY 393, } \\
\text { GLU 394, LEU 392, ARG } \\
\text { 432, ILE 391, VAL } 169\end{array}$ & 1 & TYR 153 & $\begin{array}{l}\text { TYR 153, GLU 170, GLN 150, } \\
\text { PRO 147, GLY 140, GLY 393, } \\
\text { GLU 394, LEU 392, ARG 432, } \\
\text { ILE 391, VAL } 169\end{array}$ \\
\hline Citronellol & -3.29 & $\begin{array}{l}\text { GLY 393, ARG 432, GLU } \\
\text { 394, VAL 169, TYR 153, } \\
\text { GLU 170, ASN 488, PHE } \\
\text { 137, GLU 136, GLY 140, } \\
\text { PRO 147, LEU } 392\end{array}$ & 1 & ILE 391 & $\begin{array}{l}\text { ILE 391, GLY 393, ARG 432, } \\
\text { GLU 394, VAL 169, TYR 153, } \\
\text { GLU 170, ASN 488, PHE 137, } \\
\text { GLU 136, GLY 140, PRO 147, } \\
\text { LEU } 392\end{array}$ \\
\hline Geranyl acetate & -3.02 & $\begin{array}{l}\text { GLN 150, VAL 169, GLU } \\
\text { 170, GLY 393, GLU 394, } \\
\text { ARG 432, PRO 147, GLY } \\
\text { 140, LEU 392, ILE 391, } \\
\text { MET 428, TRP } 148\end{array}$ & 1 & TYR 153 & $\begin{array}{l}\text { TYR 153, GLN 150, VAL 169, } \\
\text { GLU 170, GLY 393, GLU 394, } \\
\text { ARG 432, PRO 147, GLY 140, } \\
\text { LEU 392, ILE 391, MET 428, } \\
\text { TRP } 148\end{array}$ \\
\hline $\begin{array}{l}\text { Bicyclo[3.1.1]heptane- } \\
\text { 2Carboxaldehyde-6,6-dimethyl }\end{array}$ & -3.45 & $\begin{array}{l}\text { GLU 170, GLY 393, GLU } \\
\text { 394, ARG 432, PRO 147, } \\
\text { GLY 140, LEU 392, ILE } 391\end{array}$ & 0 & 0 & $\begin{array}{l}\text { GLU 170, GLY 393, GLU 394, } \\
\text { ARG 432, PRO 147, GLY 140, } \\
\text { LEU 392, ILE 391, }\end{array}$ \\
\hline D-limonene & -4.30 & $\begin{array}{l}\text { GLY 421, PRO 422, PHE } \\
\text { 416, ASP 413, TRP 74, HIS } \\
\text { 425, PHE 146, VAL 339, } \\
\text { TYR 388, TRP 148, CYS } 387\end{array}$ & 0 & $\mathbf{0}$ & $\begin{array}{l}\text { GLY 421, PRO 422, PHE 416, } \\
\text { ASP 413, TRP 74, HIS 425, PHE } \\
\text { 146, VAL 339, TYR 388, TRP } \\
\text { 148, CYS } 387\end{array}$ \\
\hline
\end{tabular}

result, these compounds have better inhibition potential against the virulent protein.

\section{CONCLUSION}

Planning the novel medication is a difficult issue that can be sifted through utilizing progressed computational advances (Bioinformatics). Structure-based ligand docking is a propelled apparatus being utilized for planning or contemplating the character of medication when corresponds with the destructive catalysts. The unrefined information of Apolipoprotein $\mathrm{N}$-acyl Transferase was recovered from PDB and was investigated by expelling hydrophobic particles. The medication mixes of Cymbopogon citratus were assessed utilizing ADME/T and Lipinski rule of five. Our examination uncovers that the bioactive mixes present in Cymbopogon citratus can be utilized as medication in light of the fact that these mixes won't bring about any unsafe impacts in the inside organ of human just as creature. Among all the studies compounds, 1,3,4-trimethyl -3cyclohexene-1-carboxaldehyde exhibit binding energy $-4.70 \mathrm{Kcal} / \mathrm{mol}$ followed by $\beta$-myrcene $4.35 \mathrm{Kcal} / \mathrm{mol}$ and Geraniol $-4.35 \mathrm{Kcal} / \mathrm{mol}$. The common three-letter coding amino acids involved or attached with ligand molecules are VAL 75, PHE 146, VAL 339, HIS 425, CYS 387, TRP 148, PHE 416, TYR 388, TRP 74, TYR 153, GLN 150, VAL 169, GLU 170, GLY 393, GLU 394, ARG 432, PRO 147, GLY 140, LEU 392, ILE 391, GLY 421, PRO 422, PHE 416, ASP 413, TRP 74, HIS 425, PHE 146, VAL 339, TYR 388 , TRP 148, CYS 387. We conclude that a combination of molecular docking and physiochemical properties of compounds helps to improve the potential inhibitor of the drug. For further studies, in vitro, and silico studies can be performed for developing the multiple drug target ability of Cymbopogon citratus against Apolipoprotein $\mathrm{N}$-acyl transferase.

\section{REFERENCES}

1. Poirier J, Bertrand P, Kogan S, Gauthier S, Davignon J, Bouthillier D. Apolipoprotein E polymorphism and Alzheimer's disease. The Lancet. 1993 Sep 18;342(8873):697-699.

2. Pitas RE, Boyles JK, Lee SH, Foss D, Mahley RW. Astrocytes synthesize apolipoprotein $\mathrm{E}$ and metabolize apolipoprotein E-containing lipoproteins. Biochimica et Biophysica Acta (BBA)Lipids and Lipid Metabolism. 1987 Jan 13;917(1):148-161.

3. Shah G, Shri R, Panchal V, Sharma N, Singh B, Mann AS. Scientific basis for the therapeutic use of Cymbopogon citratus, stapf (Lemon grass). Journal of advanced pharmaceutical technology \& research. 2011;2(1):3.

4. Negrelle RR, Gomes EC. Cymbopogon citratus (DC.) Stapf: chemical composition and biological activities. Revista Brasileira de Plantas Medicinais. 2007;9(1):80-92.

5. Carlini EA, De D.P. Contar J, Silva-Filho AR, Da Silveira-Filho NG, Frochtengarten ML, Bueno OFA. Pharmacology of lemongrass (Cymbopogon citratus Stapf). I. Effects of teas prepared from the leaves on laboratory animals. Journal of Ethnopharmacology. Elsevier BV; 1986 Jul;17(1):37-64.

6. Asaolu MF, Oyeyemi OA, Olanlokun JO. Chemical compositions, phytochemical constituents and in vitro biological activity of various extracts of Cymbopogon citratus. Pakistan Journal of Nutrition. 2009;8(12):1920-1922.

7. Gbenou JD, Ahounou JF, Akakpo HB, Laleye A, Yayi E, Gbaguidi F, Baba-Moussa L, Darboux R, Dansou P, Moudachirou M, Kotchoni SO. Phytochemical composition of Cymbopogon citratus and Eucalyptus citriodora essential oils and their anti-inflammatory and analgesic properties on Wistar rats. Molecular biology reports. 2013 Feb 1; 40(2):1127-1134.

8. Ajayi EO, Sadimenko AP, Afolayan AJ. GC-MS evaluation of Cymbopogon citratus (DC) Stapf oil obtained using modified hydrodistillation and microwave extraction methods. Food chemistry. 2016 Oct 15;209:262-266.

9. Biswal A, Aishwariya A, Sharma A, Pazhamalai V. 2D QSAR, ADMET prediction and multiple receptor molecular docking strategy in bioactive compounds of Gracilaria corticata against Plasmodium falciparum (contractile protein). Informatics in Medicine Unlocked. 2019 Jan 1;17:100258.

10. Meenambiga SS, Venkataraghavan R, Biswal RA. In silico analysis of plant phy tochemicals against secreted aspartic proteinase enzyme of Candida albicans. J Appl Pharm Sci. 2018 Nov;8(11):140-150. 
11. Biswal AR, Mirunalini K, Jayshree P, Pazhamalai V. Molecular Docking Analysis of Bioactive Compounds of Acacia Concinna against Fungal Protein. Journal of Pharmaceutical Sciences and Research. 2019 Apr 1;11(4):1216-1222.

12. Biswal A, Venkataraghavan R, Pazhamalai V. Molecular docking of various bioactive compounds from essential oil of Trachyaspermum ammi against the fungal enzyme Candidapepsin-1. Journal of Applied Pharmaceutical Science. 2019 May;9(05):021032.

13. Biswal RA, Jayashree P, Mirunaalini K, Pazhamalai V. Molecular docking studies of bioactive compounds from the leaves of Epiphyllum oxypetalum against Treponema pallidum, Zika virus and liver cirrhosis. Journal of Applied Pharmaceutical Science. 2019 Nov;9(11):069-077.

HOW TO CITE THIS ARTICLE: Biswal AR, Sharif RS, Pazhamalai V. Investigating Drug Properties of Bioactive Compounds of Cymbopogon citratus by Absorption, Distribution, Metabolism, Excretion/Toxicity and Molecular Docking Analysis Against Apolipoprotein N-Acyl Transferase. Int. J. Pharm. Sci. Drug Res. 2020;12(1):80-86. DOI: 10.25004/IJPSDR.2020.120113 